\title{
Meconium periorchitis: An unusual cause of newborn scrotal mass
}

\author{
Pamela Damaledo, ${ }^{1}$ Sutisna Himawan ${ }^{2}$ \\ ${ }^{1}$ Departement of Biochemistry and Molecular Biology, Faculty of Medicine University of Indonesia, Jakarta, Indonesia \\ ${ }^{2}$ Departement of Anatomical Pathology, Faculty of Medicine University of Indonesia, Jakarta, Indonesia
}

\begin{abstract}
Abstrak
Telah dilaporkan sebuah kasus periorkitis mekonium pada seorang bayi berusia 2 bulan. Penderita dilahirkan dengan normal dan ditemukan massa intraskrotum yang semakin mengeras dalam beberapa minggu. Secara klinis dan hasil pemeriksaan ultrasonografi mengesankan suatu keganasan, maka dilakukan orkidektomi. Pada pemeriksaan mikroskopik didapatkan nodul-nodul dengan stroma miksoid yang dipisahkan oleh jaringan ikat dan mengandung banyak kalsifikasi. Periorkitis mekonium merupakan suatu reaksi inflamasi terhadap mekonium di dalam rongga skrotum. Hal ini terjadi akibat perforasi traktus gastrointestinalis intrauterine. Massa solid paratestikular, baik jinak maupun ganas, sulit dibedakan melalui pemeriksaan ultrasonografi, sehingga diperlukan biopsi jaringan atau pemeriksaan potong beku untuk diagnosis. (Med J Indones 2009; 18: 290-3)
\end{abstract}

\begin{abstract}
A case of meconium periorchitis in a 2-month-old boy is reported. The patient was delivered normally, only a scrotal mass was noted which became harder in weeks. Clinical and intrauterine ultrasonographic findings were suggestive of a neoplasm and orchidectomy was performed. Microscopic examination revealed separate nodules of myxoid stroma with varying amounts of calcification separated by fibrous septa. The unexpected diagnosis of meconium periorchitis was confirmed. This condition is due to inflammatory reaction from the meconium within the scrotal sac and resulted from an intrauterine perforation of the gastrointestinal tract. Since solid benign or malignant paratesticular masses cannot be differentiated by ultrasonography, tissue biopsy or fresh frozen tissue examination is required for diagnosis.

(Med J Indones 2009; 18: 290-3)
\end{abstract}

Keywords: meconium periorchitis, paratesticular mass, scrotal mass.

Meconium periorchitis (MPO) is an uncommon benign cause of a scrotal mass in the newborn..$^{1-3}$ In utero bowel perforation can be caused by inspissated meconium associated with cystic fibrosis, bowel atresia, volvulus, or vascular compromise. Leakage of meconium into the peritoneum causes meconium peritonitis (MP). Some bowel perforations heal without obvious sequelae and the baby appears well at birth. ${ }^{1}$ Meconium reaching the paratesticular soft tissue through a patent processus vaginalis results in a scrotal mass. ${ }^{2,45}$ The typical presentation is a soft hydrocele at birth which becomes harder in weeks as the meconium calcifies. Both the masses and the calcifications have the tendency to resolve spontaneously without compromising the testicle. It mimics a scrotal mass, and without knowledge of this rare disease, this may lead to unnecessary surgery. ${ }^{1}$

Radiologic evaluation including sonographic features together with an abdominal plain film help in making the diagnosis of MPO particularly when prenatal ultrasonographic findings are suspicious for the problem. ${ }^{1,2}$ The visualization of the normal testicle shows the differentiation of this tumor-like lesion from scrotal tumors. ${ }^{2,4}$
A case of meconium periorchitis is reported and the aim is to emphasize unexpected MPO as a possible diagnostic pitfall in a newborn with a scrotal mass and recognition of this benign entity could prevent unnecessary orchidectomy.

\section{CASE REPORT}

We report a 2-month-old healthy term boy who was normally delivered following an uneventful pregnancy. A painless left scrotal mass was noted which became harder in weeks. The patient has normally descended testes and apparently did not have any difficulty in the neonatal nursery, such as delayed passage of meconium or signs of bowel obstruction.

The mass was firm and not clearly separable from the testis. There were no signs of tenderness or erythema. According to the medical record, intrauterine ultrasonography was performed and showed multiple echogenic foci with shadowing representing calcifications on the left side of the scrotum. Preoperative imaging, including ultrasonography, was not performed. Clinical laboratory 
studies, including hemograms were unremarkable. Serum alpha-fetoprotein and beta-hCG were not measured. The preoperative impression was a probable testicular neoplasm (fibroma, intrascrotal teratoma). The patient underwent left inguinal exploration through an inguinal incision and orchidectomy was performed.

Intraoperatively, a circumscribed, firm paratesticular mass was found, which was tightly adherent to the tunica vaginalis, the dissection was accomplished with some difficulty.

Gross pathologic examination revealed a mass sized $3 \times 2 \times 1.5 \mathrm{~cm}$, adjacent to a normal-sized testis $(1.4 \times 1.0$ $\mathrm{x} 0.7 \mathrm{~cm}$ ), showing gritty yellowish foci in a background of glistening yellowish to greenish stroma, and focally calcified mass. The specimen had been discarded before any gross photograph was taken.

Microscopic examination of the specimen showed a hypocellular lesion with myxoid stroma and delicate
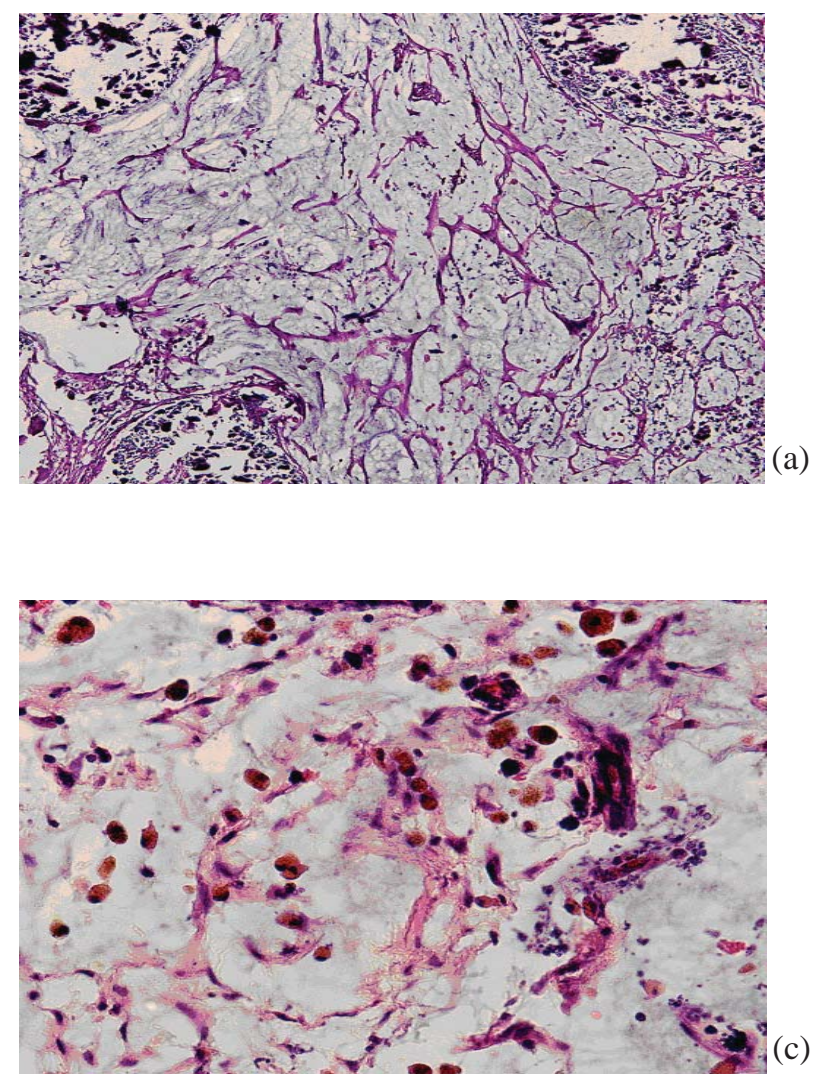

fibrous septa containing innumerable foci of blood vessels and dystrophic calcifications. No inflammatory cells, neoplasm, epithelial, or pilar elements were demonstrated. Closer inspection showed scattered aggregates of macrophages that were filled with dusty brown-yellow bile pigment which stained positively with the Stein's stain for bilirubin as granular dark brown intracytoplasmic pigment (figure 1, plane a,b,c,d). This was initially diagnosed as angiomyxoma with prominent calcifications. Since the histopathological feature and the age of the patient were not consistent with the diagnosis, the case was consulted to a urologic pathologist of the Indiana University School of Medicine in the United States. It was diagnosed as meconium periorchitis.

Plain film of the abdomen taken at three months postoperatively showed no signs of intraabdominal calcifications (fig. 2). The boy is now 16 months old and healthy.
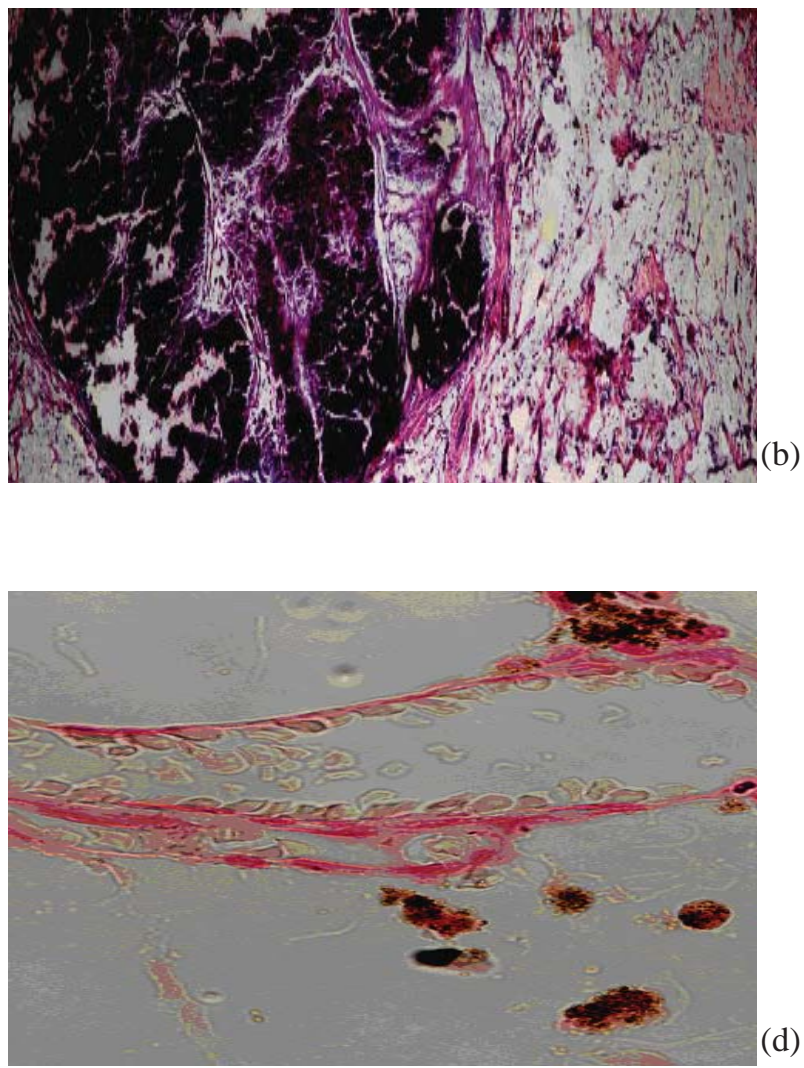

(d)

Figure 1. Histopathologic examination of the scrotal mass. (a) Myxoid stroma contained a hypocellular lesion with delicate fibrous septa and multiple foci of calcification (objective 50x); (b) Myxoid stroma with innumerable foci of blood vessel. No inflammatory cells, neoplasm, epithelial, or pilar elements were demonstrated (50x); (c) Aggregates of macrophages that were filled with dusty brown-yellow bile pigment (40x); (d) Bile pigment is seen as granular dark brown intracytoplasmic pigment (Stein, 100x) 


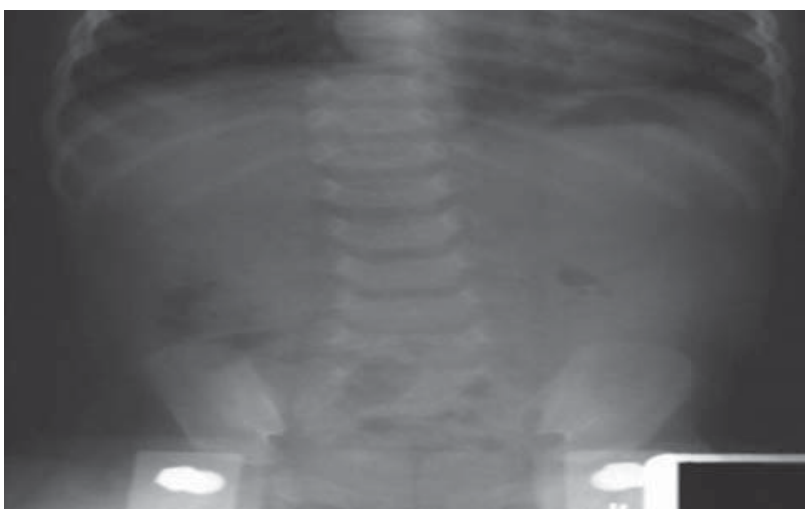

Figure 2. Plain film of the abdomen taken at three months postoperatively showed no sign of intraabdominal calcifications.

\section{DISCUSSION}

MPO was first described by Olnick and Hatcher in 1953 in an infant with scrotal and peritoneal calcification and until now about thirty cases have been reported worldwide. $^{1-3}$ Patient's age at time of diagnosis of this mass varies from birth to 20 months and typically presents in the first months of life but has been reported in children up to 5 years of age. ${ }^{2,6}$ Although others have chosen more descriptive terms, such as scrotal calcification due to meconium peritonitis, meconium in the processus vaginalis, meconium granulomas or meconium vaginalitis, we have elected to use the designation meconium periorchitis. ${ }^{6,7}$

MPO is a rare condition occurring in infant boys who have had healed meconium peritonitis. ${ }^{2,6}$ Meconium is the greenish, viscous intestinal content of the distal small bowel present after the fourth month of fetal life..$^{6-8}$ It contains swallowed amniotic fluid, bile salts, bile pigments, cholesterol, mucin, pancreatic enzymes, intestinal enzymes, squamous cells, lanugo hair and other cellular debris. ${ }^{2,6}$

Meconium peritonitis occurs when a bowel wall rupture occurs during late fetal life or early postnatal life allows meconium to enter the peritoneal cavity. This may be associated with volvulus, bowel atresia, or mesenteric vascular insufficiency. If the ruptured bowel wall heals, there may be no evidence of the cause or the site of perforation. This has been called healed meconium peritonitis. ${ }^{6,8,9,10}$

Passage of the meconium through the patent processus vaginalis, an evagination of the peritoneum from the ventral abdominal wall into the inguinal canal formed as the testis descends into the scrotum in the seventh month of gestation, may result in MPO and arises masslike lesion as a result of inflammatory reaction from meconium within the scrotal sac. ${ }^{7}$ In fetal and early postnatal periods, a patent processus vaginalis allows spilled meconium from bowel perforation to spread into the scrotal sac. ${ }^{8}$ Consistency and appearance of meconium in the scrotum evolve over time. Soft extratesticular mass at birth eventually hardens and becomes partially calcified. ${ }^{6}$

Extra-abdominal complications of meconium peritonitis have been described including passage of meconium into the scrotum through a patent processus vaginalis and into the thoracic cavity through the foramen of Bochdalek and systemic embolization of meconium. ${ }^{6,79}$

This patient demonstrates a common clinical course of MPO. The infant is clinically well at birth except for a soft scrotal mass that can be mistaken for a soft hydrocele., Within weeks to months, the mass calcifies and becomes hardened, raising the suspicion of a neoplastic process of testicular or paratesticular tissue, particularly if firm, non-tender and not clearly separable from the testis. ${ }^{1,2}$ Calcification present at birth suggests that the perforation occurred earlier in gestation. Meconium in the peritoneal cavity initiates sterile, chemical foreign body peritonitis and causes foreign-body giant-cell reaction, chronic inflammation, and finally, scarring. ${ }^{8}$ Peritoneal calcifications may develop subsequently as secondary calcification. The calcified abdominal and scrotal masses associated with MP and MPO can slowly resorb and do not require excision. ${ }^{1,6,9,10}$

Imaging studies, in particular ultrasonography, are the preferred procedure for establishing a diagnosis. ${ }^{5}$ Its ability to determine whether a scrotal mass is extraor intratesticular is important, since the majority of extratesticular lesions are benign while the majority of intratesticular lesions are malignant hence suggestive of the importance of pre-operative ultrasonographic examination. Additional use of colour Doppler ultrasonography enhances the diagnostic accuracy. ${ }^{10}$

Typically there are one or more well-defined, hyperechoic intrascrotal masses with acoustic shadowing due to calcification, closely related to the testis or epididymis. ${ }^{2,4}$ Abdominal radiographs may demonstrate peritoneal calcifications. However, as in our case, abdominal calcificationswereabsentasinapproximately $10 \%$ of cases. ${ }^{4}$ Other possible causes of scrotal calcification in infants and newborn including teratoma, gonadoblastoma, embryonal carcinoma, testicular torsion, infarction of the testis, calcifying Sertoli cell tumor and metastatic neuroblastoma, and antenatal hematoma. ${ }^{1,4,5}$ 
Paratesticular mass including rhabdomyosarcoma, metastatic neuroblastoma, lymphoma and adenomatoid tumor can have a similar appearance. ${ }^{3}$ Sonographically, malignant paratesticular tumors are described as welldefined, homogeneous or heterogeneous solid masses with echogenicity that is usually less than that of the testis. Hypoechoic or hyperechoic areas may also be seen within the mass. These ultrasonography appearances raised the suspicion of a malignant tumor in our patient. ${ }^{2}$ Other causes of scrotal mass are pseudotumor, cellular neurofibroma, which is presented as painless scrotal mass and epididymal inflammation, torsed appendix, scrotal abscess that are painful scrotal mass. ${ }^{10}$

Macroscopically, patients with MPO may have several small nodules along the spermatic cord or a large solitary mass adjacent to the testicle, as in this patient. A fibrous capsule may be present around the mass. Dystrophic calcifications are consistently found, is identified as several gritty, yellowish loci on the external and cut surfaces. ${ }^{1}$ The greenish color of meconium persists to some degree in the gross specimen, but the calcifications interact with meconium to produce a yellowish green appearance in some cases. ${ }^{2,6}$

Microscopically, fibrous septa separate nodules of myxoid stroma with varying amounts of calcification. Some of the nodules are heavily calcified, whereas others are virtually devoid of particulate precipitations. There is a striking absence of inflammation due to sterile inflammation, with the exception of scattered pigment-laden macrophages which is seen in this case. Positivity in Stein staining confirmed the bile origin of the pigment. Calcified squamous cells and lanugo are the remnants of cellular debris normally found in meconium and not indicative of mature teratoma. ${ }^{1,2,7}$

In fact most pathologists do not encounter many cases of meconium peritonitis, much less periorchitis, since even the former is a relatively rare clinical entity. If the pathologist searches carefully in sections from an atresia or stenosis of the small intestine in an infant, it is possible to identify foci of calcifications, fibrosis, and a minimal inflammatory infiltrate on the serosa or in the mesentery representing healed meconium peritonitis. ${ }^{7}$

It is important to point out that solid benign or malignant paratesticular masses cannot be differentiated by ultrasonography and require tissue biopsy or fresh frozen tissue examination for diagnosis. ${ }^{2}$ In case of MPO, surgical exploration is indicated when abdominal calcification are not present to confirm the diagnosis, a scrotal tumor is suspected or there is progressively enlargement of the testis. ${ }^{3,9}$ Most cases of MPO have been confirmed surgically, but in a case with typical sonographic findings, i.e. scrotal and abdominal calcifications, surgery might be avoided ${ }^{4}$ and the diagnosis of MPO should be considered as one of the etiologies of congenital scrotal masses in infants and young children and this may obviate unnecessary surgery. ${ }^{2}$

\section{Acknowledgement}

The authors express their gratitude to Liang Cheng, MD, Associate Professor of Pathology and Urology, Indiana University School for Medicine for his consultation report. Also to Prof. DR. Dr. Darmawan Kartono, SpBA(K) for his information and explanation and to Dr. Wirasmi Marwoto, for the Stein staining.

\section{REFERENCES}

1. Brown-Harrison MC, Harrison M, Reid BS, Cartwright PC. Meconium periorchitis - a cause of scrotal mass in the newborn. Clin Pediatr 2000;39:179-82.

2. Williams HJ, Abernethy LJ, Los.bty PD, Kotiloglu E. Meconium periorchitis - a rare cause of a paratesticular mass. Pediatr Radiol 2004;34: 421-3.

3. Algaba F, Mikuz G, Boccon-Gibod L, Trias I, Arce Y, Montironi R, et al. Pseudoneoplastic lesions of the testis and paratesticular structures. Virchows Arch 2007; 451:987-97.

4. Wax JR, Pinette MG, Cartin A, Blackstone J. Prenatal sonographic diagnosis of meconium periorchitis. J Ultrasound Med 2007;26:415-7.

5. Kalra P, Radhakhrishnan J. Meconium periorchitis. Urology 2006;68:202.

6. Dehner LP, Scott D, Stocker JT. Meconium periorchitis: A clinicopathologic study of four cases with a review of the literature. Hum Pathol 1986;17:807-812.

7. Herman TE, Siegel MJ. Meconium periorchitis. J Perinatol 2004;24:53-5.

8. Gilbert-Barnes E, Gunasekaran S. Male reproductive system. In: Gilbert-Barnes E, editor. Potter's pathology of the fetus, infant and child. 2nd ed. Philadelphia: MosbyElsevier;2007.p. 1414-26.

9. Patton WL, Lutz AM, Willmann JK, Callen P, Barkovich AJ, Gooding CA. Systemic spread of meconium peritonitis. Pediatr Radiol 1998;28:714-6.

10. Sung T, Riedlinger WFJ, Diamond DA, Chow JS. Solid extratesticular masses in children: Radiographic and pathologic correlation. AJR 2006;186:483-90. 